\title{
ПРОГНОЗ НЕФТЕГАЗОНОСНОСТИ НИЖНЕ-СРЕДНЕЮРСКИХ ОТЛОЖЕНИЙ НА ЮГЕ ТЮМЕНСКОЙ ОБЛАСТИ
}

Цимбалюк Ю.А., Вингалов В.М., Хомиұкий Е.Н., Дуборовина ЛІ.А.

(ФГУП «ЗапСибНИИГГ», г.Тюмень)

Аннотация. Представлен прогноз нефтегазоносности нижне-среднеюрских отложений на юге Тюменской области на основе палеотектонического и седиментационного анализа, динамического частотно-зависимого анализа сейсмических данных. В нижне-юрских отложениях наиболее перспективными являются структурно-стратиграфические ловушки; в средней юре - крыльевые части крупных локальньх поднятий.

Нижнекорские отложения. Тектонические движкения в пермо-триасовое время характеризовались обшей тенденщией к воздыманию земной коры, вследствие чего изучаемая территория была областью интенсивной денудации, где преобладали эрозионные процессы. В конце триасового - начале юрского периодов был сформирован равнинный рельеф с выступами наиболее консолидированных пород. Прогибание коры в раннеюрскую эпоху привело к началу формирования осадочного чехла.

Максимальные мощности юрских отложений приурочены к депрессивным зонам предъюрского палеорельефа, в которьх формирование осадочного чехла началось раньше. Морфологическая расчлененность палеорельефа сказалась на характере формирования юрских отложений, в первую очередь это выразилось в существенном различии их стратиграфического объема в палеодепрессивньг и палеоприподнятых зонах. На сводовых частях некоторых поднятий выклиниваются даже значительная часть среднеюрских и верхнеюорских пластов.

Нижнеюрский нефтегазовый комплекс на исследуемой территории включает отложения Шеркалинской свиты, содержащих два преимущественно песчаньх резервуара - пласты $Ю_{11}$ (п бах-тоар) и $Ю_{10}$ (тоар), перекрытые соответственно тогурской и радомской глинистыми пачками, являющиеся надежными флюидоупорами. Наиболее перспективными для таких условий осадконакопления в первую очередь являются структурностратиграфические ловушки, в которых одной из границ выступает зона выклинивания на доюрское основание, по принципу подопвенного налегания, а вторая граница, замыкающая изогипса структурного плана.

Среднеюрский нефтегазоносный комплекс. В границах исследуемого района среднеюрский нефтегазоносный комплекс является одним из главных продуктивных интервалов. Среднеюрский комплекс (аален-ранний келовей) включает отложения тюменской свиты с подразделениями - нижняя, средняя и верхняя подсвиты. Нижняя подсвита (аален) включает песчаные пласты Ю4-Ю7, средняя подсвита (байос) соответствуют пласты Ю6-Ю5, верхняя подсвита (бат-келловей) охватывает интервал пластов Ю4-Ю2.

На время формирования отложений тюменской свиты территория представляла собой низменную озерно-аллювиальную равнину с широко разви- той речной сетью и многочисленными озерами и болотами. В этих условиях происходило накопление разнообразных континентальных фаций с мозахчнопятнистым их распределением.

Наибольший интерес среднеюрского разреза представляют регионально продуктивные песчаные пласты $\mathrm{Ю}_{2}-\mathrm{Ю}_{4}$ верхней подсвиты.

Начавшаяся в период их формирования региональная палеогеографическая перестройка связана $\mathrm{c}$ опережаюшим прогибанием крупньх впадин (Ханты-Мансийской и Юганской), в пределах которой по пониженным участкам с севера интрессируют морские воды, в результате чего на значительных их палеопогруженных территориях, удаленной от рассматриваемой зоны, формируются крупные солонатоводные и опресненные бассейны.

Выделяемые в верхней части разреза пюменской свиты песчано-алевритовые пачки пластов $Ю_{2-}$ $Ю_{4}$ только в части случаев представляют собой относительно однородные по генезису тела, выполненные русловым аллювием, фациями прирусловых валов или дельтовыми комплексами заполнения местных областей разгрузки.

Основные палеопотоки по которым шел транзит осадочного материала в области разгрузки Ханты-Мансийскую котловину приурочены к наиболее значимым палеопрогибам унаследованные от рельефа доюрского основания.

На территории юга тюменской области открыто 16 месторождений нефти. Все они сосредоточены в северной и северо-восточной частях региона в границах Ханты-Мансийской котловины и ЮжноБортовой моноклинали за искшютением УстьТегусского месторождения, которое находится в пределах Демьянского вала.

Таким образом, наиболее благоприятными зонами для формирования как конседиментационных - литологических ловушек, так и постседиментационных струтурно - и структурно литологических выступают крыльевые части юрских крупных локальных поднятий. В осевых частях и непосредственно на сводах перспективы нахождения коллекторов существенно ниже.

По мнению авторов, существуют повышенные перспективы нефтегазносности периферийных областей развития средней юры: там, где среднеюрские пласты становятся базальными, непосредственно контактируя с доюрским основанием, и особенно в тех местах Вагай-Итимской зоны, где базальными становятся даже пласты верхнего отдела тюменской свиты $\mathrm{O}_{2}-\mathrm{Ю}_{4}$. 